\title{
Metal Recovery using Tannin Resin: An Alternative for the Treatment of Electronic Waste
}

\author{
Josiel Martins Costa*, Amanda Bensi, Gustavo Erdmann Barroso Romani, Hellynson Cássio Lana, Richard \\ Silveira Pereira and Tania Regina Giraldi
}

Instituto de Ciência e Tecnologia, Universidade Federal de Alfenas (UNIFAL-MG), Brazil

Submission: February 14, 2019; Published: February 27, 2019

*Corresponding author: Josiel Martins Costa, Instituto de Ciência e Tecnologia, Universidade Federal de Alfenas (UNIFAL-MG), Rodovia José Aurélio Vilela, 11999, BR 267, Km 533, 37715-400, Poços de Caldas, MG, Brazil

\begin{abstract}
Electronic wastes are produced from all discarded electronic materials, such as computers, cell phones, printers and televisions. With the great generation of this solid residue, it became necessary to study an environmentally suitable technique, able to recycle the metals generated by it. In this study, black wattle tannin resin was used as a potential alternative for the treatment of this waste due to its metal adsorption capacity. Black wattle resin was synthesized by using different $\mathrm{pH}$ values $(3,4,5$ and 6$)$ and particle sizes $(80,100,140$ and 200 mesh) from the standard solution of $\mathrm{AgNO}_{3}$ and solid silver dissolved into $\mathrm{HNO}_{3}$ solution. Absorption technique was used for the quantification of $\mathrm{Ag}^{+}$from samples. It was observed that $\mathrm{pH}$ values closer to neutrality (5 - 6) favor a greater adsorption of Ag+ ion as well as smaller particle sizes (granulometry of 140 - 200 mesh). From the tests of atomic absorption, a high yield of the silver adsorption by the tannin was verified, becoming the resin a viable adsorbent, as much for its efficiency, as for being a vegetal compound which does not promote the degradation of natural resources.
\end{abstract}

Keywords: Adsorption; Metals recycling; Environmentally friendly process; Tannin

\section{Introduction}

Contemporary society is experiencing great and rapid technological growth. While advances in technology make it possible to improve the medical sciences, high-speed communication, and greater access to information, on the other hand, it generates an immense accumulation of electronic waste, i.e. tablets, smartphones, televisions, among other discarded electronics. The problem generated by the high consumption of those is electronic waste, which contains toxic and polluting substances. When electronic waste is not treated, or it is recycled irregularly, it causes serious damage to the environment and human health. However, there are also metals of economic interest in discarded printed circuit boards (PCB) [1]. The recycling of electronic waste is of fundamental importance for the global ecosystem, due to the large volume generated, and for the economy, since metals of commercial value can be found in plates of cell phones and computers [2].

An alternative in the techniques of recycling metals is the use of tannin resin [3-6]. Tannins are polyphenols obtained from vegetable matrices, widely used in textile industries and found in many species plant, for example, black acacia (Acacia mearnsii De Wild) [7-10]. Since tannins contain an abundant amount of adjacent hydroxyl groups in their molecules, they form chelates with metals and can be classified as hydrolyzable and condensed $[11,12]$. These plant species are studied not only in the removal of metals from wastewater but also in the recovery of noble metals, such as gold, based on the complexing and reducing properties of tannins [13]. From the reaction of this substance with oxalic acid $\left(\mathrm{H}_{2} \mathrm{C}_{2} \mathrm{O}_{4}\right)$, formaldehyde $\left(\mathrm{H}_{2} \mathrm{CO}\right)$ and water under heating and reflux, the resin is obtained $[8,9]$. By synthesizing the resin, it is possible to make metallic ions in solution to be adsorbed on the surface of these resins, thus extracting them from the solution [14].

The application of low-cost absorbent materials can be advantageous when compared to other traditional processes such as reverse osmosis, solvent extraction, chemical precipitation, filtration, electrode deposition and evaporation [6]. In this context, it is necessary to investigate techniques for the metal recovery that are environmentally suitable and present satisfactory efficiency. For this purpose, the objective of this paper was to quantify the adsorption capacity of the tannin resin using a standard solution of silver ions (Part I) and subsequent use of silver ions solution from solid silver (Part II), in order to compare the results in different $\mathrm{pH}$ values and resin granulometry.

\section{Materials and Methods}

\section{Synthesis of tannin resin of black wattle (Acacia mearn- sii De Wild)}

$30 \mathrm{~g}$ of tannin was weighed and solubilized in distilled water at $60^{\circ} \mathrm{C}$. The mixture was transferred to a round bottom flask where it remained under heating and reflux. $0.5 \mathrm{~g}$ of oxalic acid $\left(\mathrm{H}_{2} \mathrm{C}_{2} \mathrm{O}_{4}\right)$ was added, remaining for $60 \mathrm{~min}$ under heating and refluxing. It 
was added over $20 \mathrm{~mL}$ of formaldehyde $\left(\mathrm{H}_{2} \mathrm{CO}\right)$ and $10 \mathrm{~mL}$ of saturated solution of oxalic acid remained for a further $30 \mathrm{~min}$ under reflux. After this time, $100 \mathrm{~mL}$ of heated distilled water was added to promote separation of the phases. This step remained for an additional $60 \mathrm{~min}$ under the above conditions. The product was cooled, subjected to vacuum filtration, and then transferred to a clock glass, for oven drying at $40^{\circ} \mathrm{C}$ for $24 \mathrm{~h}[8,9,15]$. Figure 1 shows the final product obtained.

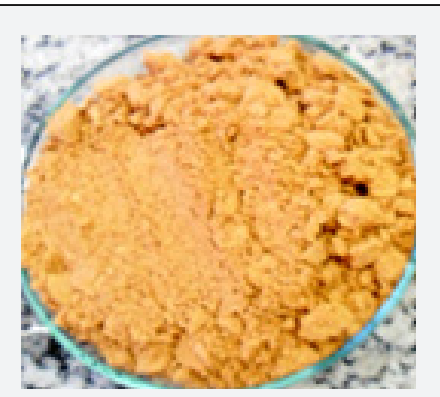

Figure 1: Tannin resin obtained of Acacia mearnsii De Wild.

Part 1: Preparation of atomic absorption assays by varying the $\mathrm{pH}$ and in different granulometries from silver standard solution

Before the measurements of ions adsorption on the tannin resin are carried out, silver standard solutions are prepared from the aqueous silver nitrate solution concentration of $0.1 \mathrm{~g} \mathrm{~L}^{-1}$ (analytical reagent). In the analyzes performed, it was initially verified the ability of the resin to absorb silver ions at different $\mathrm{pH}$ in order to obtain the ideal $\mathrm{pH}$ for a better absorption. Thus, 4 samples were used, varying the $\mathrm{pH}$ in the values of $3,4,5$ and 6 .

It was added $1 \mathrm{~g}$ of tannin resin (granulometry obtained in the 100 -mesh sieve) in $100 \mathrm{~mL}$ of $0.1 \mathrm{~g} \mathrm{~L}^{-1} \mathrm{AgNO}_{3}$ solution. The $\mathrm{pH}$ was then adjusted to 3 (adding $0.1 \mathrm{M} \mathrm{HNO}_{3}$ solution) and the sample was placed on the magnetic stirrer for $80 \mathrm{~min} .15 \mathrm{~mL}$ of the sample was removed and transferred to a vessel to be taken in the centrifuge for $12 \mathrm{~min}$ at $2500 \mathrm{rpm}$. The supernatant was removed and transferred to a labeled tube called Sample 1. The same procedure was performed for Sample 2. For Sample 3 instead of adding 0.1 molar $\mathrm{HNO}_{3}, 0.5$ molar $\mathrm{NaOH}$ was added to regulate the $\mathrm{pH}$, since the $\mathrm{pH}$ of the resin with the silver nitrate solution was around 4.

From the analysis at different $\mathrm{pH}$ values, it was observed an ideal $\mathrm{pH}$ for the adsorption of silver through the resin. Once the optimum $\mathrm{pH}$ was defined, the other variable studied was the granulometry of the resins. It used a same $\mathrm{pH}$ (the $\mathrm{pH}$ that promoted better silver adsorption by the resin) for the 4 samples and only changing the granulometry of the tannin resin.

In samples 5, 6 and 7 the same pH range (5.0) was used, since the literature reports that this value is considered an ideal value for adsorption of the silver ions in the tannin resin, since acidic medium and were not beneficial $[16,17]$. The $\mathrm{pH}$ was controlled by the addition of 0.5 molar $\mathrm{NaOH}$ solution. The other procedures were also performed for samples 5, 6 and 7. The temperature of the samples was $25.5^{\circ} \mathrm{C}$ during the experiment. The samples were analyzed by the atomic absorption technique. The Table 1 containing the variables analyzed in the experiment. For all samples, the ratio was $1 \mathrm{~g}$ of resin to $100 \mathrm{~mL}$ of $5.8810^{-4} \mathrm{M} \mathrm{AgNO}_{3}$ solution.

Table 1: Variables analyzed in part I of the experiment.

\begin{tabular}{|c|c|c|}
\hline Sample & Granulometry (Mesh) & $\mathbf{p H}$ \\
\hline 1 & 100 & 3 \\
\hline 2 & 100 & 4 \\
\hline 3 & 100 & 5 \\
\hline 4 & 100 & 6 \\
\hline 5 & 80 & 5 \\
\hline 6 & 200 & 5 \\
\hline 7 & 140 & 5 \\
\hline
\end{tabular}

\section{Obtaining solid silver from a solution of silver nitrate} $\left(\mathrm{AgNO}_{3}\right)$ and posteriorly ionic silver

The experiment consisted of using two $100 \mathrm{~mL}$ beakers with approximately $70 \mathrm{~mL}$ of $0.1 \mathrm{M} \mathrm{AgNO}_{3}$ solution in each. Several copper wires were added in the beakers and the deposition of a dark-looking solid on the wires was noted. This solid was silver metal, since silver underwent oxidation by gaining electrons from copper. In this way, copper oxidation occurred, presenting a blue coloration in the characteristic solution when it is in ionized solution. The wires remained for $10 \mathrm{~min}$ in the solution. The wires were removed and the solid deposited on the wire was scraped using a spatula. The solid was washed through vacuum filtration and dried in the oven at $60^{\circ} \mathrm{C}$ for one h. The reaction 1 occurred:

$$
\mathrm{AgNO}_{3(a q)}+\mathrm{Cu}_{(s)} \rightarrow \mathrm{CuNO}_{3(a q)}+\mathrm{Ag}_{(s)}
$$

In order to obtain the ionic silver, $\mathrm{HNO}_{3}$ was used to open the solid silver and to obtain $1 \mathrm{~L}$ of $0.1 \mathrm{~g} \mathrm{~L}^{-1} \mathrm{AgNO}_{3}$ solution. Such concentration is the same throughout the experiment, with the aim of comparing results. The chemical reactions 2 and 3 describe the obtaining of solid silver and the recycle of $\mathrm{HNO}_{3}$.

$$
\begin{gathered}
6 \mathrm{Ag}_{(s)}+8 \mathrm{HNO}_{3(a q)} \rightarrow 6 \mathrm{AgNO}_{3(a q)}+4 \mathrm{H}_{2} \mathrm{O}_{(a q)}+2 \mathrm{NO} \uparrow_{(g)} \\
4 \mathrm{NO} \uparrow_{(g)}+3 \mathrm{O}_{2(g)}+2 \mathrm{H}_{2} \mathrm{O}_{(a q)} \rightarrow 4 \mathrm{HNO}_{3(a q)}
\end{gathered}
$$

\section{Part II: Preparation of atomic absorption assays by varying the $\mathrm{pH}$ and different granulometries using ion- ic silver from dissolved solid silver}

The atomic absorption test was performed according to item 2.2. The 100-mesh sieve was used for the sieving of the resin of tannin in $100 \mathrm{~mL}$ of $0.1 \mathrm{~g} \mathrm{~L}^{-1} \mathrm{AgNO}_{3}$ solution. The $\mathrm{pH}$ of the samples was adjusted by adding $0.1 \mathrm{M} \mathrm{HNO}_{3}$ or $0.5 \mathrm{M} \mathrm{NaOH}$ solution as required. Samples were placed on the magnetic stirrer for $80 \mathrm{~min}$. $15 \mathrm{~mL}$ was withdrawn from the sample and transferred to a vessel to be taken in the centrifuge for $12 \mathrm{~min}$ at $2500 \mathrm{rpm}$. Subsequently, the supernatant was removed and transferred to a labeled tube in order to be observed by the atomic absorption technique. In samples 5, 6 and 7 the same pH range (5.0) was used and according to item 2.2. The variations in grain size were the same, according to Table 1 . For all samples, the ratio was $1 \mathrm{~g}$ of resin to $100 \mathrm{~mL}$ of 
$5.88 \times 10^{-4}$ molar $\mathrm{AgNO}_{3}$ solution. The samples were analyzed using atomic absorption spectrometer with flame.

\section{Results and Discussion}

\section{General information}

As previously mentioned, to verify the efficiency of the tannin resin in capturing $\mathrm{Ag}^{+}$ions of silver aqueous solutions, two variables were used: the $\mathrm{pH}$ of the solution and the grain size of the Table 2: Results obtained in the part I and II. resin. Table 2 indicates the results obtained from the studied variables from part I and II, being the measures of atomic absorption of the solutions after remaining in contact with the tannin resin. Since the result is the amount of $\mathrm{mg} \mathrm{L}^{-1} \mathrm{Ag}^{+}$present in the supernatant liquid, and it being known that the initial $\mathrm{Ag}^{+}$ion concentration was $0.1 \mathrm{~g} \mathrm{~L}^{-1}$ i.e. $100 \mathrm{mg} \mathrm{L}^{-1}$, one can obtain the amount that was probably adsorbed by the resin, being subtracted from the initial concentration by the result of the atomic absorption.

\begin{tabular}{|c|c|c|c|c|c|c|}
\hline \multirow{2}{*}{ Sample } & \multirow{2}{*}{ Granulometry (Mesh) } & \multirow{2}{*}{ pH } & \multicolumn{2}{|c|}{ Result (mg L ${ }^{-1}$ of $\mathrm{Ag}+$ ) } & \multicolumn{2}{|c|}{ Amount adsorbed (mg L $\mathrm{m}^{-1}$ of $\mathrm{Ag}+$ ) } \\
\hline & & & Part I & Part II & Part I & Part II \\
\hline 1 & 100 & 3 & 34.8 & 18.2 & 65.2 & 81.8 \\
\hline 2 & 100 & 4 & 35.8 & 15.4 & 64.2 & 84.6 \\
\hline 3 & 100 & 5 & 30.6 & 17 & 69.4 & 83 \\
\hline 4 & 100 & 6 & 20.1 & 12.4 & 79.9 & 87.6 \\
\hline 5 & 80 & 5 & 41.8 & 16.7 & 58.2 & 83.3 \\
\hline 6 & 200 & 5 & 31 & 14 & 69 & 86 \\
\hline 7 & 140 & 5 & 30 & 16.9 & 70 & 83.1 \\
\hline
\end{tabular}

\section{Evaluation of $\mathrm{pH}$}

When analyzing the results of the samples with different $\mathrm{pH}$, it was possible to verify that the $\mathrm{pH}$ influences the adsorption of the ions in the resin. It is observed that acid $\mathrm{pH}$ is not favorable for the adsorption process, since the concentration of $\mathrm{Ag}^{+}$at $\mathrm{pH} 3$ is $34.8 \mathrm{mg} \mathrm{L}^{-1}$. This indicates that in this condition, $65.2 \mathrm{mg}$ of $\mathrm{Ag}^{+}$was adsorbed by the resin, while at higher $\mathrm{pH}$ values, as in the case of the $\mathrm{pH} 6$ solution, the amount of $\mathrm{Ag}^{+}$adsorbed by the resin was $79.9 \mathrm{mg}$. At low $\mathrm{pH}$ levels, competition between the $\mathrm{H}^{+}$ions and the metal ions $\left(\mathrm{Ag}^{+}\right)$of the resin may occur, making it difficult to adsorb [16]. In the case of $\mathrm{pH}$ higher than 6, the $\mathrm{Ag}^{+}$ions precipitate and the phenolic groups of the tannin resin would be oxidized $[10,18]$, that is, basic $\mathrm{pH}$ is also not favorable for the adsorption process.

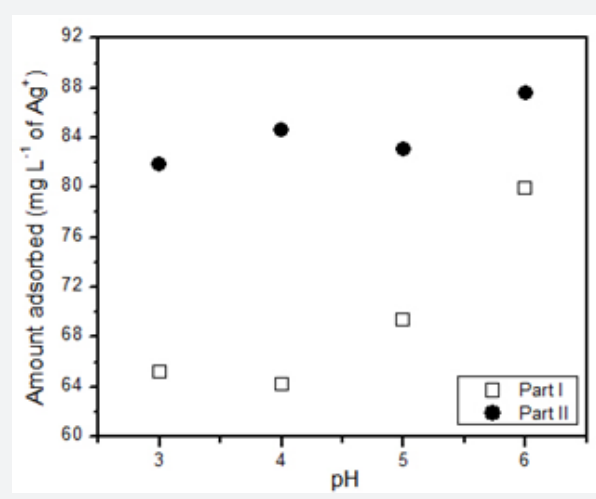

Figure 2: $\mathrm{Ag}+$ ion adsorption as a function of the $\mathrm{pH}$ in part I and II.

With these results, it was possible to obtain a graph (Figure 2) that relates the $\mathrm{pH}$ of the solution to the amount of $\mathrm{Ag}^{+}$adsorbed by the resin. In this way, pH 5 was used as the reference for studies of the influence of grain size, since the literature reports that it is an ideal $\mathrm{pH}$ range [18]. In this work, it was verified that solutions with $\mathrm{pH} 6$ presented better adsorption results of $\mathrm{Ag}^{+}$ions. However, with the experimental conditions, it is not possible to affirm that this is a significant difference in relation to what the literature reports, that is, better results in solutions with $\mathrm{pH}$ 5. As previously mentioned, in addition to the assays at different $\mathrm{pH}$, assays with different particle sizes were carried out. The use of $\mathrm{pH} 5$ solutions for the four samples was standardized in these cases.

Comparing the adsorption result of $\mathrm{Ag}^{+}$from part I to part II, at different $\mathrm{pH}$ values, it was verified that there is a certain relation, since the $\mathrm{pH}$ of greater adsorption in part I was also the one with higher value in part II. However, the adsorption values of part II are higher. This may have occurred because the $\mathrm{Ag}^{+}$ions were not adsorbed totally on the tannin resin, since the adsorption is an estimate, and $\mathrm{Ag}^{+}$ions can react with other compounds that were present in the solution, as for example the resin itself, the acid and the base that were used to regulate the $\mathrm{pH}$ of the solution. In this second part, the sample that presented the highest adsorption by

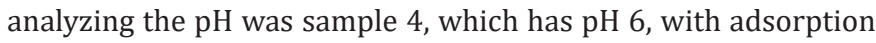
in the resin of $87.6 \mathrm{mgL}^{-1}$ of $\mathrm{Ag}^{+}$, being this $\mathrm{pH}$ value with the highest adsorption also in the result of part I. In this way it is not possible to describe again a significant difference, since experimental errors must be considered.

\section{Evaluation of resin granulometry}

From the Table 2, a graph (Figure 3) with the behavior of the $\mathrm{Ag}^{+}$ion adsorption was obtained as a function of the granulometry of the tannin resin. It can be seen in Figure 3 that the resin of 80 mesh granulometry provided a lower $\mathrm{Ag}^{+}$adsorption. This fact can be explained due to the contact surface of the particles. It is noteworthy that in the 80 mesh sieve the particles were larger than in the other sieves. The size of the grains of the phenolic resins is also of great relevance, and according to the results obtained, it was 
noticed that smaller particles adsorb greater amounts of ions of the metal. This is due to smaller particles have larger surface area, and this favors the adsorption of a larger quantity of ions [18]. The amount of $\mathrm{Ag}^{+}$adsorbed on the resins obtained with the other sieves practically remained constant, with little oscillation of the adsorbed amounts. The small decrease in the sieve from 140 to 200 mesh may have occurred due to experimental errors during the execution of the experiment. Again, the adsorption values are higher than in part I, even though the same concentration of $\mathrm{Ag}^{+}$ is in solution. This may have occurred according to the previously described factors, noting that there was an attempt to perform part II equal to part I, however experimental errors may have occurred which affect the results. A literature divergence, which also occurred in part I, in which a larger particle (80 mesh) has higher adsorption (83.3 $\mathrm{mg} \mathrm{L}^{-1} \mathrm{Ag}^{+}$) than a smaller particle (100 mesh) has a larger contact surface (83.0 $\mathrm{mg} \mathrm{L}^{-1}$ of $\mathrm{Ag}^{+}$). This divergence is not very significant and is worth the same justification of the other discussions.

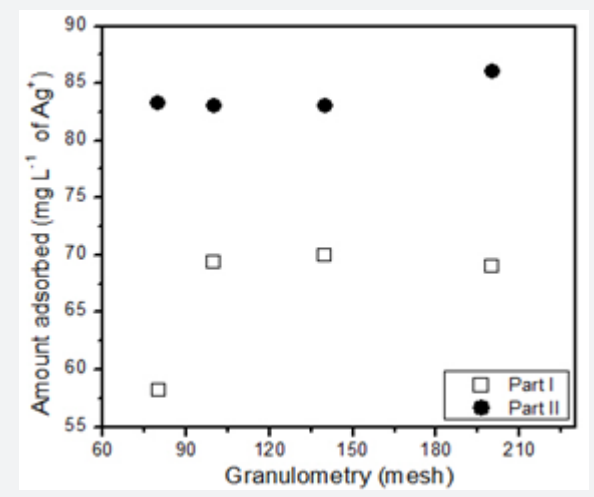

Figure 3: $\mathrm{Ag}+$ ion adsorption as a function of the resin granulometry in part I and II.

\section{Conclusion}

It was possible to synthesize the tannin resin from the powder. Tests were performed with the resin at different $\mathrm{pH}$ and granulometry. For $\mathrm{pH}$ values the adsorption efficiency was not efficient as well as for larger particle size. Already for the $\mathrm{pH}$ value equal to 5 - 6 and granulometry equal to 140 - 200 mesh as adsorption efficiencies were high, due to the equilibrium between $\mathrm{H}^{+}, \mathrm{OH}^{-}$and $\mathrm{Ag}^{+}$ions and higher surface area. Thus, black wattle tannin resin as adsorbent of metallic ions from printed circuit boards (PCB) presents a viable option, since it is a vegetal compound and not toxic to the environment.

\section{Acknowledgment}

This study was supported by Tanac S/A Company and Universidade Federal de Alfenas.

\section{References}

1. Park YJ, Fray DJ (2009) Recovery of high purity precious metals from printed circuit boards. J Hazard Mater 164(2-3): 1152-1158.
2. Li J, Lu H, Guo J, Xu Z, Zhou Y (2007) Recycle technology for recovering resources and products from waste printed circuit boards. Environ Sci Technol 41(6): 1995-2000.

3. Gurung M, Adhikari BB, Alam S, Kawakita H, Ohto K, et al. (2013) Persimmon tannin-based new sorption material for resource recycling and recovery of precious metals. Chemical Engineering Journal 228: 405-414.

4. Gurung M, Adhikari BB, Kawakita H, Ohto K, Inoue K, et al. (2011) Recovery of $\mathrm{Au}(\mathrm{III})$ by using low cost adsorbent prepared from persimmon tannin extract. Chemical Engineering Journal 174(2-3): 556-563.

5. Nakajima A, Sakaguchi T (1993) Uptake and recovery of gold by immobilized persimmon tannin. J Chem Technol Biotechnol 57(4): 321-326.

6. Tondi G, Oo CW, Pizzi A, Trosac A, Thevenon MF (2009) Metal adsorption of tannin based rigid foams. Industrial Crops and Products 29(2-3): 336-340.

7. De Bruyne T, Pieters L, Deelstra H, Vlietinck A (1999) Condensed vegetable tannins: biodiversity in structure and biological activities. Biochemical Systematics and Ecology 27(4): 445-459.

8. Ogata T, Nakano Y (2005) Mechanism of gold recovery from aqueous solutions using a novel tannin gel adsorbent synthesized from natural condensed tannin. Water Research 39(18): 4281-4286.

9. Ogata T, Kim YH, Nakano Y (2007) Selective recovery process for gold utilizing a functional gel derived from natural condensed tannin. Journal of Chemical Engineering of Japan 40(3): 270-274.

10. Sengil A, Ozacar M (2008) Biosorption of Cu(II) from aqueous solutions by mimosa gel. J Hazard Mater 157(2-3): 277-285.

11. Rahim AA, Rocca E, Steinmetz J, Kassim MJ, Adnan R, et al. (2007) Mangrove tannins and their flavanoid monomers as alternative steel corrosion inhibitors in acidic medium. Corrosion Science 49(2): 402417.

12. Yurtsever M, Sengil IA (2009) Biosorption of $\mathrm{Pb}(\mathrm{II})$ ions by modified quebracho tannin resin. J Hazard Mater 163(1): 58-64.

13. Nakano Y, Takeshita K (2005) Mechanisms of gold recovery from aqueous solutions using a novel tannin gel adsorbent synthesized from natural condensed tannin. Water Research 39: 4281-4286.

14. Bacelo HAM, Santos SCR, Botelho CMS (2016) Tannin-based biosorbents for environmental applications - A review. Chemical Engineering Journal 303: 575-587.

15. Lee W, Lan W (2006) Properties of resorcinol-tannin-formaldehyde copolymer resins prepared from the bark extracts of Taiwan Acacia and China fir. Bioresour Technol 97(2): 257-264.

16. Kratochvil D, Volesky B (1998) Advances in the biosorption of heavy metals. Trends in Biotechnology 16(7): 291-300.

17. Nakano Y, Takeshita K, Tsutsumi T (2001) Adsorption mechanism of hexavalent chromium byredox within condensed-tannin gel. Water Research 35(2): 496-500.

18. Liu Y, Liu Y (2008) Biosorption isotherms, kinetics and thermodynamics. Separation and Purification Technology 61(3): 229-242. 


(CC) Commons Attribution 4.0 License
DOI: 10.19080/IJESNR.2019.17.555967

\section{Your next submission with Juniper Publishers will reach you the below assets}

- Quality Editorial service

- Swift Peer Review

- Reprints availability

- E-prints Service

- Manuscript Podcast for convenient understanding

- Global attainment for your research

- Manuscript accessibility in different formats

( Pdf, E-pub, Full Text, Audio)

- Unceasing customer service

Track the below URL for one-step submission https://juniperpublishers.com/online-submission.php 